\title{
STRENGTH ANALYSIS IN DESIGN CODES AND SOFTWARE
}

\author{
Anatoly V. Perelmuter \\ SCAD Soft Ltd, Kyiv, UKRAINE
}

\begin{abstract}
Modern building design standards have a long history. During this time, they have undergone a number of changes, but some of their provisions and recommendations, once proclaimed, remain unchanged. And although they do not meet the modern possibilities of computational analysis, but continue to exist due to the established tradition. In this paper, attention is paid to only some of the mentioned conflicts, which are related to the software implementation of regulatory requirements.
\end{abstract}

Keywords: load-bearing capacity, building codes, computer analysis

\section{ПРОЧНОСТНОЙ РАСЧЕТ В НОРМАХ ПРОЕКТИРОВАНИЯ И В ПРОГРАММНЫХ СИСТЕМАХ}

\author{
А.В. Перельмутер \\ SCAD Soft, г. Киев, УКРАИНА
}

\begin{abstract}
Аннотация. Современные нормы строительного проектирования имеют уже довольно длинную историю. За это время они претерпели ряд изменений, но некоторые их положения и рекомендации, будучи раз провозглашенными, остаются неизменными. И хотя они не соответствуют современным возможностями расчетного анализа, но продолжают свое существование в силу сложившейся традиции. В этой работе обращается внимание лишь на некоторые из упомянутых коллизий, связанных с программной реализацией нормативных требований.
\end{abstract}

Ключевые слова: несущая способность, строительные нормы, компьютерный анализ

\section{INTRODUCTION}

The experience of design activity in recent decades shows that the development of automation of engineering calculations has the most serious impact (unfortunately, both positive and negative) on the quality of justifications for design decisions. The level of detail and accuracy of calculation, which is now available to designers en masse, yesterday was still unattainable even for the most qualified organizations and professionals. At the same time, the availability of modern powerful computing systems creates a number of new problems. One of them is the growing number of inconsistencies between the capabilities of software systems, which are focused on a detailed analysis of the work of structures, and the requirements of regulations, which are focused on established experience.

Almost all modern tools of building design automation implement to some extent the requirements of existing regulations. At the same time the inclusion of regulatory requirements in software systems is not only a problem of their developers, but also a problem of a wide range of users. The point is that users have to understand which requirements for regulatory documents can and should be imposed on the relevant software, when deciding on its use. An almost complete disarray takes place here today. Some users would like everything to be implemented (including departmental, company and other detailed 
instructions), others would like the developers to allow them to decide which rules should be followed and which can be ignored, still others want detailed references to justify regulatory requirements and etc.

Of course, one can rely on the following principle. The implementation of regulatory requirements in the software must strictly adhere to the text of the regulatory document. In cases where this is not possible in general (examples of such a situation are given below), the program should refuse to perform the appropriate function in the part that does not adequately reflect norms, notifying the user. In this case, an accurate reflection of possible limitations of this kind in the program documentation should be a prerequisite.

Another set of problems is due to the fact that modern software systems focus on the use of universal provisions of such disciplines as the theory of elasticity, the theory of plasticity, structural mechanics, etc. while some provisions of the norms are based on simplified approaches, test results and experience of operation of existing structures. But being presented in the regulatory document, such provisions suddenly take advantage over scientifically sound and more accurate solutions, which do not appear in the codes only due to the complexity of calculations. Almost all modern tools of construction design automation implement to some extent the requirements of existing regulations. Meanwhile there are certain problems of technical, legal and economic nature, which often arise due to the fact that the developers of regulations did not forecast the possibility (and necessity!) of their software interpretation.

\section{TWO INTERPRETATIONS OF THE CONCEPT OF "CALCULATION OF STRUCTURES"}

The design justification of design decisions is a multi-stage process, in which, at least, two main parts should be distinguished: calculation of the stress-strain state (SSS) and verification of the accepted cross sections (or their reinforcement).
Unfortunately, this fact is not emphasized and when talking about the calculation of structures is not always clearly stated what we are talking about.

At the same time from the point of view of rationing the differences here are fundamental: the calculation of SSS is the problem of structural mechanics and this process in principle should not be the subject of rationing, while checking the bearing capacity of sections is a conditional procedure aimed at achieving a certain degree of safety. The rationing, i.e. the establishment of certain requirements of society, is quite appropriate here.

Returning to the stage of the SSS calculation, we can say that only some "permitting procedures", which establish acceptable simplifications of the problem, can be controlled by the design code. It is important to note here that it is a question of allowable simplifications, instead of their obligatory application though in texts of regulatory documents this fundamental difference is not stipulated in any way. The question arises here about the inequality of the results of the simplified calculation performed in accordance with design standards and the possible result of a more accurate analysis.

It should be noted that modern software systems often have the ability to perform the structure calculation in much more detail and accuracy than required by regulations. Such details of the stressstrain state and such details of the behavior of the structure under load can be found, which were not taken into account by the authors of the normative document or, more often, taken into account in the design standards by applying some special coefficient of working conditions or other ways to take into account additional bearing capacity. Since these techniques are not deciphered in detail in the regulations, the corresponding feature may be taken into account twice: the first time in the framework of computer simulation and the second time in the regulatory verification, which is performed using the above additional coefficient. As a result (and this has happened many times) a project with a more thorough calculation 
justification will be less economical than a rougher calculation according to the standards.

The situation may be even more complicated when the normative document provides for a calculation procedure in which some empirical correction factors are used. A typical example is the standards for seismic analysis of structures [3], where the results of the response specrtum method are adjusted by the reduction factor K1, which is introduced to take into account the plastic behavior and local damage. Since the degree of plasticization of structural elements and the amount of local damage is not specified, it remains unclear what to look for when using other methods of calculation (direct integration of equations of motion, deformation method of checking the ultimate forces, etc.).

Another example is the calculation for temperature effects. The fact is that the design standards of structures set the maximum distances between the temperature seams (see, for example, section 15.1 of the Russian construction code SP 16.13330.2017 [5]). Traditionally, it is considered that the calculation of temperature effects can be omitted when a compartment length does not exceed these limits. But it has been repeatedly detected that such a calculation leads to the conclusion of a significant overstrain of the loadbearing structures, which causes surprise and numerous discussions.

The discovered contradiction is due to the fact that the standard calculation models of force calculation do not take into account some flexibility of the nodal joints (for example, slippage of the base of the steel column on the foundation within the black holes for anchor bolts). Such shifts, which are absolutely insignificant under force loading, are decisive under the kinematical influence of the thermal deformation type. Their values may be compared with thermal elongations and they dramatically affect the stress-strain state. Here, the rules, which are based on many years of practical experience, are "smarter" than traditional analysis. Thus, it can be stated that if the calculation model adopted for computer analysis of the structure does not correspond to the model that was meant when compiling the regulatory document, there may be contradictions or inaccuracies that cannot be resolved without decoding the approach adopted in the standards. Unfortunately, such a decoding is not provided in our rationing system.

\section{ON REGULATION OF CALCULATION METHODS}

Although the science of "structural mechanics" can not set standards, if we keep in mind the methods and rules of calculation, but when it comes to choosing a calculation model, the question is not so clear.

The fact is that the design standards are a chain of trade-offs, where some inaccuracies in the calculation of some parameters (e.g., internal efforts in the system) are offset by safety factors embedded in other parameters (e.g., in the design strength). In addition, the method used by the authors of the rules can be based on a certain calculation model, and this model occurs to be specified in the normative document.

Traditionally, building design standards have focused on certain set of calculation schemes. Most often, these were plane bar systems loaded in one plane or in mutually orthogonal planes and operating in a uniaxial stress state. Spatial structures, especially of shell type, are considered much less often. However, they are almost standard when calculating using software. And here there is a certain imbalance of possibilities, when many cases, normalized for traditional calculations, are simply absent for the calculations of spatial systems.

As an example, let us mention the fact that the design standards for steel and reinforced concrete structures provide a material stress-strain diagram only for uniaxial state and there are no recommendations for assessing the performance of structures in $2 \mathrm{D}$ or $3 \mathrm{D}$ stress state. In this case, the normative documents on the design of reinforced concrete structures, which are calculated by a nonlinear deformation model, for example, are focused on checking the values of ultimate deformations, but such criteria are given 
only for uniaxial stress state. How they should be transformed with respect to the $2 \mathrm{D}$ stress state is completely unclear. After all, there is no theoretical justification for the use of deformation criteria here. Moreover, any theory of plasticity is based on the concept of the boundary surface in the stress space, whereas the concept of the boundary surface in the space of deformations simply does not exist.

Another problem concerns the interpretation of the results of the spatial calculation model analysis in accordance with the regulatory documents. So, for example, for bar elements we receive six internal forces and $N, M_{x}, Q_{y}, M_{y}, Q_{x}, M_{z}$ instead of three $N, M, Q$ and even if any element works "in plane" that nonzero values (probably small on size) can have all six internal forces. How small must be certain forces, so that they can be neglected, is not specified.

For example, the concept of a beam used in [5] and [4], obviously implies the ability to neglect the influence of longitudinal force in comparison with the influence of moments. But if in the first case for steel structures in 9.2.2 there is a record that for the value of the given relative eccentricity $m_{e f}>20$ the calculation can be performed as for the bent element (i.e. to neglect the influence of longitudinal force), then for reinforced concrete structures such idealization is not defined. And for steel structures, the limit $m_{e f}=20$ is specified to test the stability, and whether this recommendation of standards allows a common interpretation is unknown.

Of course, a competent engineer can determine this limit in each case, but some rule is required for the software implementation, and its absence creates a situation for unnecessary controversy. The above is a fairly typical situation when the normative document contains some information (for example, tabular values), but in the program it is more profitable to calculate them than to borrow it from the table. What degree of disagreement is permissible (or non-existent) is the subject of many meaningless discussions. But the requirements of design norms are not laws of nature, they only approximate these laws with one or another degree of accuracy. Unfortunately, information about the errors that are permissible according to regulatory documents can be found nowhere. The only exception that can be found is the use of 10.0 instead of the exact value of the acceleration of gravity 9.81 when converting the normative values of loads from $\mathrm{kPa}$ in $\mathrm{kgf} / \mathrm{m}^{2}$ in building regulations SNiP 2.01.07-85* of 1985 edition or 0.1 instead of $1 / \pi^{2}$ in the formula (108) of building rules SP 16.13330.2017.

The problem of joining results at conditional borders is connected with the delimitation of basic concepts. Since some simplifying hypotheses were used in various variants of the stress-strain state, belonging to one or another category of normalization (compressed-bent bar, bent beam, etc.), it is often difficult to implement a smooth border crossing.

Especially many problems are connected with necessity (possibility, desirability?) of performance of the general static calculation taking into account geometrical and physical nonlinearity declared by standards.

However, the following question remains unclear. Is it possible to apply the results of the calculation which was performed taking into account geometry changes if it concerns the coefficient of longitudinal bending $\varphi$ ? This coefficient is of great importance for the stability of compressed steel rods analysis and calculated using deformed model (but for the element, not entire system).

\section{PROBLEMS THAT CANNOT BE SOLVED WHEN USING NONLINEAR CALCULATION}

For a number of computational cases that inevitably arise in the actual design, regulations establish rules necessarily requiring a linear approach to solving the problem. An example is dynamic analysis closely related to such concepts of linear dynamics of structures as the frequency and mode of the natural vibrations of the system. For a nonlinear system, the very concept of individual forms of natural oscillations disappears and all recommendations based on this (i.e. the procedure 
of decomposition of motion into a superposition of normal modes) lose their meaning.

An alternative approach suitable for accounting for nonlinear effects is sometimes (though rarely) present in standards, such as direct dynamic calculation by instrumental or synthesized accelerograms, but more often it is not only not mentioned, but simply not developed. Analysis of the response to the pulsating wind loadings can be typical here.

Another problem that is not solved in the nonlinear analysis is the problem of choosing unfavorable load combination. In practice, there are virtually no structures that work only on one load option. It is usually necessary to anticipate the possibility of the occurrence of many temporary loads and, therefore, it is necessary to somehow determine their estimated combination. This problem has a solution with a linear approach to the calculation, when you can use the principle of superposition. If you focus on nonlinear analysis, then at the same time you should specify for which combination of loads you should perform strength and stability analysis. This type of instructions in regulations is often missing.

\section{STABLE EQUILIBRIUM}

Examination of the equilibrium stability of the complex bar type structure in the general case requires the calculation accounting the geometric nonlinearity and inelastic operation of the structural elements. Calculation of this type, in addition to computational complexity, also requires overcoming a number of other difficulties associated with the great uncertainty of the design assumptions (patterns of load change, idealization of material properties, initial irregularities, residual stresses, etc.). In this regard, in engineering practice there is a tradition of performing an idealized elastic calculation of the stability of the system as a whole in combination with checking individual elements for which more detailed account of the inelastic behavior of the material, initial bends and eccentricities and other circumstances is performed.
Most often, the stability problem is replaced by a refined calculation of the deformed model with increasing bending moments in compressed bars or other similar way by multiplying by some buckling length coefficient $\varphi$ or coefficient of bending moments increasing $\eta=1 /\left(1-N / N_{c r}\right)$. The critical value (in the sense of loss of stability) of the value of compressive force takes part in the choice of the value of these coefficients and this fact ties the calculation of the deformed model to the stability analysis of the idealized model.

A natural question arises about the relationship between these two approaches. To what extent and for what purposes can their results be used separately and what is the link between them? It is believed that the bridge that combines these two approaches will be the buckling lengths of the elements of the system. Therefore, the fundamental question is of the method of determining the buckling lengths.

Note also that the use of the concept of buckling length involves the division of bar type systems into separate elements, it is necessary to take into account the interaction of the element with the foundation and other elements (primarily adjacent to it in the nodes).

The logic of most of the standards recommendations is focused on flat computational models or, at least, on a separate consideration of the spatial scheme in two orthogonal planes. If we turn to spatial systems, they may have difficulties of a completely different kind, associated with the use of the concept of flexibility in the two orthogonal planes of inertia of the bar element.

Following the classical approach of F.S. Yasinski [10], the buckling length of the bar is usually understood as the conditional length $\mathrm{f}$ a simple bar, the critical force of which when hinged its ends is the same as for a given rod. In terms of physical content, the buckling length of the bar with arbitrary fixings is the largest distance between two inflection points of the bent axis, which are determined from the stability analysis of this bar by the Euler method.

In the works of Yasinski himself and in numerous subsequent works, where the concept of the 
buckling length of the bar appears, the use of plane calculation models and, accordingly, plane deformation models is implicitly implied. Only for them it makes sense to consider the distance between the inflection points of the curved axis, taken as the calculated length.

Since even for plane models, the buckling length of compressed bars should be determined both in the plane and from the plane of the system, then here there is a mismatch with the definition of F.S. Yasinski. Indeed, imagine a spatial cantilever bar in which the cross section has moments of inertia $J_{x}$ and $J_{y}=4 J_{x}$. Under central compression, such a bar loses stability under load $P_{c r, x}=\pi^{2} E J_{x}$./ $(2 l)^{2}\left(l_{e f, x}=2 l\right)$.

From the point of view of standards, apparently, it is possible to imagine a situation when two calculations on stability are performed during which deformation in one or in another main plane of inertia is alternately forbidden (for example, considering that $J_{x}=\infty$ and then $J_{y}=\infty$ ), and after that the coefficients of the buckling length $\mu_{x}$ and $\mu_{y}$ are determined. But, as far as we know, for any complex systems, such even calculations in design practice are not performed.

Other problems arise when in the spatial system the main axes of inertia of the elements are not parallel to each other and the mode of stability loss, as well as the free lengths, is dependent on the orientation of these axes.

A fairly typical example is shown in Fig. 1, which shows the modes of stability loss and values of critical loads for two structures, which differ in that the cross-sections of the struts have different orientations of the main axes of inertia.

The model showed in Fig. 1 (a) has the coefficient of the buckling length in the plane of minimum rigidity $\mu_{x}=0,597$, while the model showed in Fig. 1 (б) has $\mu_{x}=0,523$. In the first case, the loss of stability mode is such that all the column are deformed in the plane of least rigidity. In the second case such deformation is observed only in two columns while the other two are deformed in the plane of greatest rigidity.

It should be noted that the solution of F.S. Yasinski refers to an elastic centrally compressed bar of constant cross-section, which when lost stability buckles in the form of a plane curve. Since the magnitude of the free length does not depend on the transverse load and is determined only by boundary conditions, this concept has been extended to elastic eccentrically compressed elements that bend in one of the main planes of inertia. Therefore, the in plane bending is

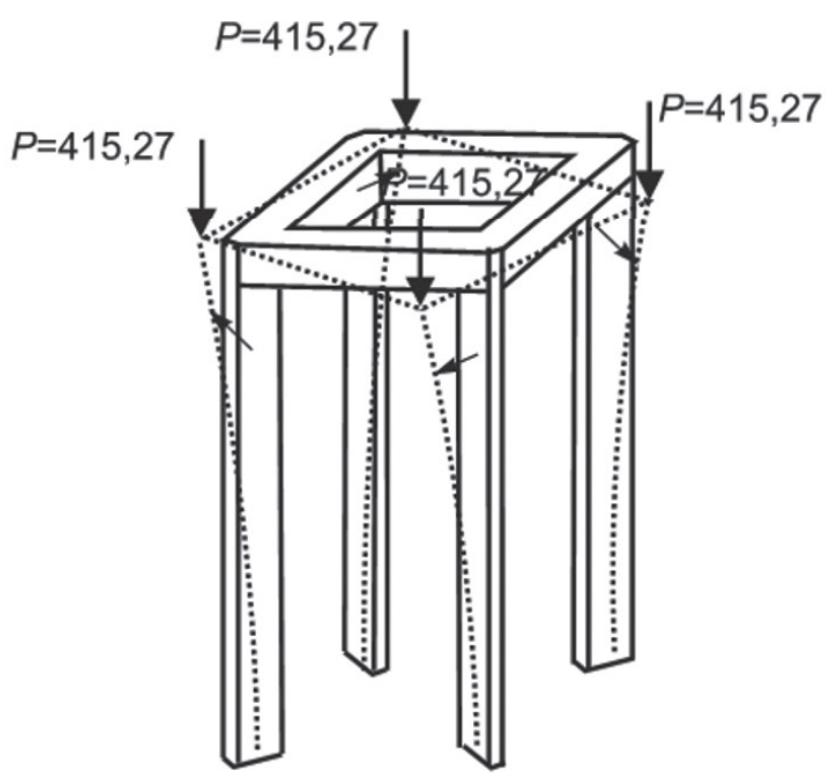

(a)

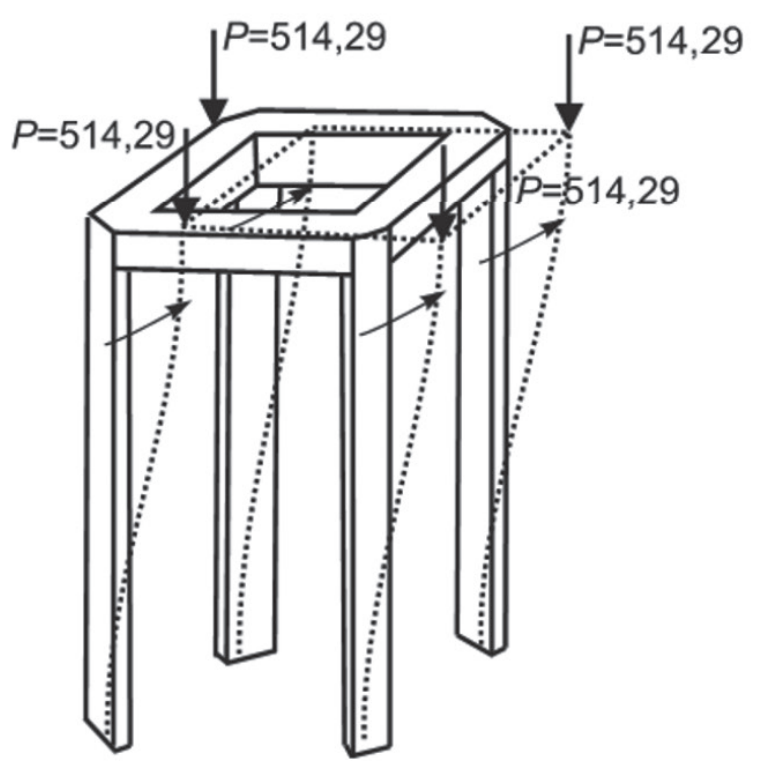

(b)

Figure. 1. Sample of analysis 
implicitly assumed, because only in this case it makes sense to consider the distance between the inflection points of the bent axis, taken as the buckling length.

However, even a single bar can lose stability by having a spatial bending curve that occurs, for example, when the ends of the bar have cylindrical hinges whose axes are not parallel to each other. Another example that limits the scope of the classical concept of the buckling length is the case of the torsional mode of stability loss. A number of other examples that indicate the difficulties arising here are given, for example, in [6].

However, the convenience of using the concept of the buckling length has made this method extremely popular, in almost all countries it is included in the regulations governing the verification of the bar structures equilibrium stability.

The buckling length of the elastic bar was used for normative calculation in the inelastic stage of the bar loading. It should be recognized that there is, in fact, no clear theoretical justification for this, and it should be considered a heuristic technique. And the widespread use of this technique is most likely due to the fact that engineers needed at least some practical method of calculating the bar structures for stability. Therefore clarity, associated with the solution of the simplest problems, replaced the reasoning of accuracy.

\section{DYNAMIC CALCULATIONS}

Almost all regulations in the field of dynamics focus on the use of decomposition into modes of natural vibrations. Thus, the use of linear equations is implicitly assumed, and only in a few cases do software systems consider the linearized behavior of a nonlinearly deformable structure, i.e. analyze small oscillations around the deformed equilibrium position.

When focusing on the eigenmode decomposition, many regulatory documents indicate the number of eigenvalue forms to be taken into account, with no indication of the calculation model used. As a result, it has repeatedly happened that the first few natural frequencies (namely they are recommended to take into account by the standards) determine the local partial modes of motion, while the main mode of deformation is not the first.

The second problem of dynamic calculations, which is often mentioned indirectly by regulations, is the excessive simplification of dynamic models. This simplification due to tradition is often perceived as a characteristic of real behavior, which can lead to misunderstandings. Thus, the long-standing habit of using the cantilever calculation model in the seismic analysis has led to the fact that the detection of torsional vibrations as one of the lower is treated as a shortcoming, although no one could indicate what is the defect of this design.

It is necessary to mention one more aspect of dynamic calculations using eigenmode decomposition. It is associated with summation of modal contributions, which often follows the well-known "root-sum-squares" (RSS) rule. But this approach is based on the hypothesis that all modal reactions are normally distributed random variables with the same correlation coefficients, which is consistent with many observations, although not an established fact. Therefore, the absolutization of the RSS rule is rather doubtful. An example is the calculation using the accelerogram in those models where the equations of motion are solved by eigenmode decomposition, and summation fulfilled according to the RSS rule. But if the integration of equations of motion is performed, for example, by the Adams method, then we come to a completely different result. Nevertheless, since one and the same problem was solved, the result should not depend on the method of its solution.

The summation of internal forces, which are calculated by the usual rules for each of the eigenmodes, is also performed by the RSS method, but there may be another disappointment. The use of modules of moments, longitudinal and shear forces leads, for example, to disappearing of compressed-bent bars, that is all of them become stretched-bent. Similar effects of sign loss are possible in shell-type elements. To overcome this phenomenon in some software systems, the 
total values of internal forces are assigned signs, as in similar forces corresponding to the first eigenmode. It is difficult to substantiate such an approach, even if we assume that it is the first eigenmode that realizes the main contribution to the total value of each of the components of the response vector.

\section{ACCURACY REQUIREMENTS}

Verification of compliance with structural design standards sometimes leads to uncertainties or errors due to the fact that the standards describe only one load or one stress-strain state. Detailed recommendations are given for this isolated situation, and in such a "ultimate" formulation (for example, as a calculation formula), which does not allow to understand what type of assumptions and simplifications were used. But in the real calculation it may be necessary to consider a less refined case and then there arise a number of difficulties.

As an example, we can point to the stability analysis of the plane bending of steel structures. The coefficient $\varphi_{b}$, the value of which is calculated in accordance with SP 16.13330.2017 and depends, inter alia, on the location of the load within the beam height of. But it may happen that the calculated combination of loads contains loads located both above and below the beam. In this case, the direct use of the rules becomes impossible.

If we take the opportunity to study the shell model of a thin-walled bar and with sufficiently detailed modeling to solve the problem of plane bending stability using the finite element method, it turns out that in the case of exact coincidence of loading options with the normative situation, we will get a solution. which does not coincide with the provisions of the design codes. This is because some approximations of exact expressions were laid down in the formulas of the appendix G [5], by means of which the coefficients $\varphi_{b}$ are calculated. The discrepancy may be small, but the rules by which they can be considered acceptable are unknown.

What degree of discrepancy is acceptable is the subject of much nonsensical debate. But the requirements of design standards are not laws of nature, they only approximate these laws with one or another degree of accuracy. Unfortunately, nowhere can be found information about the errors that allowed by the authors of the standards. The only exception that can be found is the use of the value of 10,0 instead of the exact value of the acceleration of gravity 9,81 when translating the normative values loads from $\mathrm{kPa}$ to $\mathrm{kgf} / \mathrm{m}^{2}$ in building regulations SNiP 2.01.07-85* of 1985 edition or 0,1 instead of $1 \wedge \pi^{2}$ in the formula (108) of building rules SP 16.13330.2017.

The problem of permissible discrepancy of results arises when the rules have some alternatives. The developers themselves were more likely to compare the results (if any) for a "typical case", but such a comparison does not follow a good correlation of the results in any case. An example is the analysis of methods for determining the width of cracks presented in [9], when the use of different alternative solutions, allowed by the standards showed more than $59 \%$ variance of the results.

There should be some measure which allow estimate the result of the comparison. After all, in engineering calculations there is no complete coincidence of results. The generally accepted norm of similarity in the form of a five percent discrepancy must also be specified and it is necessary to know to what results (displacement, effort, etc.) and to what values (extreme, average or other) it should refer. This problem would be greatly mitigated if the comparison was conducted only by the designer. However, submitted to the experts, such comparisons will be the subject of numerous and often pointless discussions.

\section{PROGRAMMING AS A MEANS OF CONTROLLING A REGULATORY DOCUMENT}

In the pre-computer period, the vague or ambiguous recommendations, although they were evil, but this evil was not as dangerous as it is today. Today, formal compliance with the rules in the software package is hidden from the eyes of the end user, and an unambiguous interpretation of the new paragraphs of the rules is primarily needed by 
software developers. And these points themselves should be set out in the wording, which should be in the nature of a clearly defined algorithm of action. It seems to us that this cannot be achieved without certain organizational changes.

Software implementation of the normative document is a good test procedure, which reveals discrepancies, logical inconsistencies, incompleteness and vagueness of the formulation and other shortcomings of the draft rules, in particular, compatibility with computer methods of analysis. As an example, we can refer to the construction of the bearing area of the element taking into account the full range of proposed requirements $[7,2]$ which revealed some inconsistencies that lead to the rupture of the boundary and non-convexity of the permissible loads area. The construction of this area is based on the analysis of calculations that contain several hundred variants of the internal forces values. Such mass verification was simply impossible in the era of manual arithmetic.

In addition, programming reveals those aspects of the normative document that are not formulated explicitly, as the developers of the norms focused on a qualified user who can independently decide on the use of a provision, based on the specifics of the calculation situation. This is not possible for a computer program, so it will definitely be installed during programming.

It is important that such verification work is performed without the participation of the developers of the regulatory document, which would ensure the purity of the experiment.

\section{POSSIBLE ACTIONS}

How can the contradiction between the desire to develop simple and understandable design rules (traditional approach to rationing) and the ability of modern computer systems to solve problems without the use of dubious simplifications (modernist approach) be eliminated?

It seems to us that two solutions are possible here: - develop different versions of regulations for manual and computer calculation;
- create a special regulatory and methodological document on the rules for implementing the requirements of design standards in software.

The first option can be implemented in the traditional form, when formulating general requirements and necessary hypotheses, based on which one can create a software implementation. After that there appears a text such as "allowed ...", which presents a simplified version of the standardized provision.

And in the second option, the document should reflect: - requirements for accuracy of calculations and permissible deviations from the literal implementation of regulatory guidelines;

- the procedure for verification and coordination with the authors of the standards concerning methods of numerical solution of design problems, which expand the possibilities of verifying regulatory requirements, but not available for manual calculation;

- requirements for software developers to inform users about the peculiarities of the implementation of regulatory requirements in case of deviation from their literal implementation.

\section{REFERENCES}

1. Bazhenov V.A., Vabishchevych M.O., Vorona Yu.V., Pyskunov S.O., Perelmuter A.V., Solodei I.I. Kompiuterni tekhnolohii rozrakhunku prostorovykh konstruktsii pry statychnykh i dynamichnykh navantazhenniakh [Computer technologies for computation of spatial constructions under static and dynamic loadings (in Ukrainian)]. - K.: Karavela, 2018. - 312 p.

2. Gavrilenko I., Girenko S., Perelmuter A., Perelmuter M., Yurchenko V. Load-bearing capacity as an interactive analysis tool in SCAD Office // Proceding of the METNET Seminar 2017 in Cottbus. - Hämeelinna: HAMK, 2017. - P. 112-127.

3. Russian construction code SP 14.13330.2018 Stroitelstvo v sejsmicheskikh rajonakh [Seismic building design code]. - Moscow: Standartinform, 2018. - 122 p. (rus) 
4. Russian construction code SP 63.13330.2018 Betonnye i zhelezobetonnye konstrukcii. Osnovnye polozheniya [Concrete and reinforced concrete structures. General provisions] Moscow: Minstroii Rossii, 2018. -143 p. (rus).

5. Russian construction code SP 16.13330.2017 Stalnye konstrukcii [Steel structures]. Moscow: Minstroii Rossii, 2017. - 145 p. (rus)

6. Perelmuter A.V., Slyvker V.Y. Raschetnye modeli sooruzheniy i vozmozhnost ikh analiza [Design models of structures and the possibility of their analysis (in Russian)]. - 4-e izd., pererabotannoye i dopolnennoye. - M.: SKAD SOFT, 2020. - 736 p.

7. Perelmuter A.V., Tur V.V.Hotovy li my pereity k nelineinomu analizu pri proektirovanii? [Are we ready to move on to nonlinear analysis in design? (in Russian)] // International Journal for Computational Civil and Structural Engineering, 2017. - Vol. 13, No 3. -C. 86-102.

8. Perelmuter A.V., Yurchenko V.V. Doslidzhennia oblasti nesuchoi zdatnosti tonkostinnykh sterzhnevykh elementiv iz kholodnohnutykh profiliv [Load-bearing capacity analysis of thin bar elements from cold rolled profiles (in Ukrainian)] // Nauka ta budivnytstvo, 2019, V. 21 № 3. - P. 42-48.

9. Perelmuter M.A., Popok K.V., Skoruk L.N. Raschet shyriny raskrytia normalnykh treshchyn po SP 63.13330.2012 [Calculation of the opening width of normal cracks according to Building Rules SP 63.13330.2012 (in Russian)] // Beton i zhelezobeton, 2014, № 1. - P. 21-22.

10. Yasynskiy F.S. Izbrannye raboty po ustoichivosti szhatykh sterzhnei [Selected works on the stability of compressed bars (in Russian)]. - M.-L.: Gostekhyzdat,1952.

\section{СПИСОК ЛИТЕРАТУРЫ}

1. Баженов В.А., Вабищевич М.О., Ворона Ю.В., Пискунов С.А., Перельмутер А.В.,
Солодей И.И. Компьютерные технологии расчета пространственных конструкций при статических и динамических нагрузках. Киев: Каравелла, 2018. 312 с. (на украинском)

2. Gavrilenko I., Girenko S., Perelmuter A., Perelmuter M., Yurchenko V. Load-bearing capacity as an interactive analysis tool in SCAD Office // Proceding of the METNET Seminar 2017 in Cottbus. Hämeelinna: HAMK, 2017. - P. 112-127.

3. СП 14.13330.2018 Строительство в сейсмических районах. Актуализированная редакция СНиП II-7-81*. М.: Стандартинформ, 2018. $122 \mathrm{c}$.

4. СП 63.13330.2018 Бетонные и железобетонные конструкции. Основные положения. СНиП 52-01-2003. М.: Минстрой России, 2018. 143 с.

5. СП 16.13330.2017 Стальные конструкции. Актуализированная редакция СНиП II-2381*. М Минстрой России, 2017. 145 с.

6. Перельмутер А.В., Сливкер В.И. Расчетные модели сооружений и возможность их анализа. 4-е изд., перераб. и дополн-е. - М.: Изд-во СКАД СОФТ, 2017. - 736 с.

7. Перельмутер А.В., Тур В.В. Готовы ли мы перейти к нелинейному анализу при проектировании? // International Journal for Computational Civil and Structural Engineering, 2017. Vol. 13, No 3. - C. 86-102.

8. Перельмутер А.В., Юрченко В.В. Исследлвание области несущей способности тонкостенных стержневых элементов из холодногнутых профилей // Наука та будівництво, 2019, Том 21 № 3. - С. 42-48.

9. Перельмутер М.А., Попок К.В., Скорук Л.Н. Расчет ширины раскрытия нормальных трещин по СП 63.13330.2012 // Бетон и железобетон, 2014, № 1. - С. 21-22.

10. Ясинский Ф.С. Избранные работы по устойчивости сжатых стержней. - М.-Л.: Гостехиздат, 1952. 
СП 63.13330.2018 Бетонные и железобетонные конструкции. Основные положения. СНиП 52-01-2003

СП 16.13330.2017 "Стальные конструкции. Актуализированная редакция СНиП II-23-81*"

Russian construction code SP 295.1325800.2017 Konstruktsii betonnyye, armirovannyye polimernoy kompozitnoy armaturoy. Pravila proyektirovaniya [Concrete structures reinforced with polymer composite reinforcement. Design rules]. Moscow: Standartinform, 2017. 48 p. (rus)

СП 14.13330.2018 Строительство в сейсмических районах. Актуализированная редакция СНиП II-7-81* Seismic building design code

СП 16.13330.2017 "Стальные конструкции. Актуализированная редакция СНиП II-23-81*" Steel structures

СП 63.13330.2018 Бетонные и железобетонные конструкции. Основные положения. СНиП 52-01-2003 Concrete and reinforced concrete structures. General provisions
СП 63.13330.2012 Бетонные и железобетонные конструкции. Основные положения. Актуализированная редакция СНиП 52-01-2003 Concrete and won concrete construction. Design requirements

Russian construction code SP 14.13330.2018 Stroitelstvo v sejsmicheskikh rajonakh [Seismic building design code] Moscow: Standartinform, 2018. 122 p. (rus)

Russian construction code SP 16.13330.2017 Stalnye konstrukcii [Steel structures] Moscow: Minstroii Rossii, 2017. 145 p. (rus)

Russian construction code SP 63.13330.2018 Betonnye i zhelezobetonnye konstrukcii. Osnovnye polozheniya [Concrete and reinforced concrete structures. General provisions] Moscow: Minstroii Rossii, 2018. 143 p. (rus).

Russian construction code SP 63.13330.2012 Betonnye i zhelezobetonnye konstrukcii. Osnovnye polozheniya [Concrete and won concrete construction. Design requirements] Aktualizirovannaya redakciya SNiP 52-01-2003.
Anatolii $V$. Perelmuter, Foreign member of Russian Academy of Architecture and Construction Sciences, Doctor of Science, Professor; SCAD Soft, Ltd; Kiev 03037, Ukraine, 3a Osvity street, office. 1,2; phones: +38 044249 7193 (91), +38 04424871 00, +38 04424880 60; e-mail: avp@scadsoft.com.
Перельмутер Анатолий Викторович, иностранный член PAАCH, доктор технических наук, профессор; НПО СКАД Софт, 03037, Украина, г. Киев, ул. Просвящения, 3а, Офис 2; тел. +38 0442497193 (91), +38 04424871 00, +38 04424880 60; E-mail: avp@scadsoft.com. 